\title{
Effect of Mulching on Crop Production under Rainfed Condition: A Review
}

\author{
Shilpa ${ }^{1}$, Parveen Sharma ${ }^{1}$, Priyanka Bijalwan ${ }^{2}$
}

10.18805/ag.R-1937

\begin{abstract}
As the population of India is continuously rising so we have to adopt some means of sustaining our agricultural growth and it can be done through conservation farming. The best way out is the adoption of the age old practice of mulching in our agricultural fields. Mulching is an agricultural and horticultural technique in which the use of organic materials and synthetic materials for the purpose of increasing soil productivity is involved. In rainfed area, judicious use of water is essential for improving crop productivity. Therefore, mulching has been advocated as an effective means for conserving soil moisture. This technique is very useful in protecting the roots of the plants from heat, cold or drought or to keep fruit free from diseases and insect pests. Mulching is an old age technique to conserve soil moisture, checks evaporation, check the weed growth, moderate soil temperature and provide congenial microclimatic conditions for plant growth and development. This technology is a boon for the horticulture crops not only for increasing growth, development, yield but also a method for soil and water conservation. This review paper deals with the various effects of mulching on plants, soil as well as on soil microflora. This technology has brought a great revolution in the agriculture especially for water conservation and proves to be a fastest growing plasticultural technique in the world.
\end{abstract}

Key words: Moisture conservation, Microclimate, Mulch, Organic matter, Polyethylene soil productivity.

The word mulch has been probably derived from the German word "molsch" means soft to decay, which apparently referred to the use of straw and leaves as a spread over the ground as mulch. Any material used (spread) at surface or vertically in soil to assist soil and water conservation and soil productivity in arid and semi-arid regions is called as mulch. This practice of applying mulches to soil is possibly as old as agriculture itself.

Mulching as an application of layer of covering material on the soil surface. As stated by Bhavani (1960), mulching appears to be a very ancient Chinese practice employed to conserve the scanty supply of moisture available for growing melons. Other reasons for use of mulching include congenial soil temperature, weed control, soil conservation;water conservation and improvement in soil physical, chemical and biological properties and after the decomposition of organic mulch add plant nutrients which ultimately enhances the growth and yield of crops (Dilip et al., 1990).

Mulches are either organic or inorganic. Organic mulches are those derived from plant and animal origin. Those most frequently used include plant residues such as straw, hay, leaf mold and compost, wood products such as sawdust, wood chips and animal manures. However, natural mulch materials are often not available in adequate quantities for commercial operations or such mulch material must be transported to the place of use and thus require considerable hand labour. Inorganic mulch includes plastic mulch such as poly vinyl chloride or polyethylene films and accounts for the greatest volume of mulch use in commercial crop production. Due to greater permeability of plastic mulch to long wave radiation which can increase soil and air
'Department of Vegetable Science and Floriculture, Chaudhary Sarwan Kumar Himachal Pradesh Krishi Vishvavidyalaya, Palampur-176 001, Himachal Pradesh, India.

${ }^{2}$ Defence Institute of Bio-Energy Research, DRDO, Pithoragarh262 501, Uttarakhand, India.

Corresponding Author: Shilpa, Department of Vegetable Science and Floriculture, Chaudhary Sarwan Kumar Himachal Pradesh Krishi Vishvavidyalaya, Palampur-176 001, Himachal Pradesh, India. Email: shilpavij1212@gmail.com

How to cite this article: Shilpa, Sharma, P. and Bijalwan, P. (2021). Effect of Mulching on Crop Production under Rainfed Condition: A Review. Agricultural Reviews. DOI: 10.18805/ag.R-1937.

Submitted: 30-08-2019 Accepted: 01-06-2021 Online: 14-08-2021

temperature around the plants during night in winter. Hence, polyethylene film mulch is preferred as better mulching material for crop production. Now a days, particularly in rainfed agriculture, application of black plastic mulch film is becoming very popular. The beneficial effects of organic and inorganic mulches for crop production have been discussed by Ravi and Lourduraj (1996). Organic mulches have the advantage of being biodegradable in nature, but consequently decomposition of organic matter may result in a temporary reduction in soil mineral nitrogen and other nutrients also. During the decomposition of the material which is organic in nature various phytotoxins are released which avoids the growth of weeds and sometimes also harmful for the major crop and do not let it to grow properly. The use of black polythene mulch is restricted to the perennial crops but found to be superior than any other mulch. Today the vast majority 
of plastic mulch is based on LLDPE because it is more economic in use under arid and semi-arid regions.

Murugan and Gopinath (2001) verified the efficacy of organic mulches (dried leaves, coconut fronds and coir pith) and inorganic mulches (black polyethylene 25, 50 and $100 \mu$ ) on growth attributes of Saundaryacv of Crossandra at Bangalore. According to Arora et al., 2002 likewise, different cultivars of carnation under poly house showed significant improvement in plant height, number of branches, flower size and yield with the application of black polyethylene mulch. The basic objective to write the review paper is that to understand the effects of mulches on soil as well as on the plants.

\section{Effect of mulches on soil and plants}

\section{Conserve soil moisture}

The conservation of soil moisture through mulching is one of the important purposedue to modification of micro-climate conditions in the soil. Organic mulch helps to prevent the weed growth, reduces the evapo-transpiration rate and also increases the infiltration rate of rain-water in the soil during the crop growing season. In addition plastic mulch helps to prevent the excessive water loss away from the crop root zone during periods of excessive rain fall which can decrease the irrigation frequency and amount of water used. Mulch can also reduces the incidence of the various physiological disorders related to soil moisture such as Blossom end rot in various vegetable crops and fruit cracking in lime and also in pomegranate (Mohapatra et al., 1999). Thakur et al. (2000) observed that plastic mulch had highest water use efficiency and different mulching materials such as grass, lantana leaves and plastic, helped bell pepper (Capsicum annuum cv. California Wonder) to perform better even at water deficits from 25 to $75 \%$. According to Hatfield et al. (2001) crop residue mulching helps in $34-50 \%$ reduction in soil water evaporation. Khurshid et al. (2006), Muhammad et al. (2009) stated the same results that mulching helps to improve the ecological environment of the soil and thus it avoids decrease in soil water levels.

\section{Reduced infiltration rate}

The presence of mulch at the soil-atmosphere interface has a direct influence on infiltration of rainwater and evaporation by obstructing the solar radiation reaching to soil and there byenhances the total intake of water due to formation of loose soil surface. The water infiltrated in soil can be utilized by crops there-by crop yields are increased. Infiltration and soil evaporation are among the key processes that determine soil water availability to crops in semi arid agriculture.

Abu-Awwad (1999) revealed that covering of soil surface reduced the amount of irrigation water required by the pepper 14 to $29 \%$ and the onion crop by $70 \%$, respectively. Erenstein, 2002 conducted thetrialsin the higher potential areas of Zimbabwe between 1988 and 1995 indicated that mulching significantly reduced surface runoff and infiltration.
According to Khurshid et al. (2006), mulch cover reduces surface runoff and holds rainwater at the soil surface thereby giving it more time to infiltrate into the soil.

\section{Reduced weed growth and keep the crop clean}

Mulching provides a physical barrier, thus reduces the germination and nourishment of many weeds. Mulching materials such as wheat straw, dry grasses and saw dust proves to be good for inhibiting the growth of many weeds. According to Pimpini (1974) in a study revealed that the plastic mulching improves the growth of eggplant by checking the weed growth. Because mulching leads to improved and higher soil moisture by favouring the reduction of evaporation. Covering or mulching the soil surface can prevent weed seed germination or physically suppress seedling emergence. Ossom et al. (2003) stated that saw dust is a wonderful soil improver and weed suppressor as it conserves soil moisture, decreases run-off, increases infiltration and percolation, decreases evaporation, etc. and weed growth can be substantial under clear mulch. They also observed significant differences in weed control between mulched and unmulched plots of eggplant, cowpea and sweet potato and concluded the same as above.

\section{Reduced pest infestation}

The transparent polyethylene mulch has been found to reduce the whitefly populations, aphids were also caught in yellow traps and reduced viral diseases incidence, in comparison to bare soil. The reflective plastic mulches can also reduce the incidence of aphid-borne viruses by confusing aphids and possibility of excluding some species of insect-pest.

The main properties of transparent polythene mulch is repellent effect on pest and also on the insect vectors, such as aphids, whiteflies and thrips. The mode of action of the transparent mulch is probably the high reflectance of UV light. A beneficial effect of clear mulch on reduction of aphid population was recorded by Farias-Larios and OrozcoSantos (1997b). The success of living mulches is the suppression of pests and weeds population.

\section{Maintain soil temperature}

By reducing the temperature during the summers and maintaining the optimum temperature during winters is the main beneficial effect of the mulches by reflecting and transmitting the solar energy. The main purpose of the white mulch is reduction of temperature while clear plastic mulch increases the temperature. The plastic mulching increased soil temperature by 0.9 to $4.3^{\circ} \mathrm{C}$ at the seedling stage, 1.6 to $2.3^{\circ} \mathrm{C}$ at the bud initiation stage and 0.8 to $1.9^{\circ} \mathrm{C}$ at the flowering stage (Chen and Katan (1980). According to Sarolia and Bhardwaj (2012), wheat straw mulch raised the soil temperature by $2-3^{\circ} \mathrm{C}$ in peak winter season. At night, condensation on the underside of the mulch absorbs the long wave radiation emitted by the soil thereby slowing cooling of the soil (Lamont, 2005). In general, the effect of mulching on the temperature regime of soil varied depending 
on capacity of the mulch materials to reflect and transmit solar energy (Lamont, 2005). Black mulch materials have specific optical properties due to which mulches control soil temperature, which can augment or reduce crop yield (Kader et al., 2017). Plastic film mulching absorbs solar radiations and reduces soil heat loss with a consequent increase in soil moisture and temperature, both of which augment plant growth and improve crop production as, the effects of soil temperature on crop growth are also related to the climatic conditions and locations, where the crop plants are grown. Colour of plastic mulch material determines the energyradiating factors by influencing the surface temperature of the mulch and the underlying soil temperature. However, the effect of mulching materials on soil temperature is highly variable. The timing of soil temperature measurements and mulching thickness also cause variation in data pertaining to soil temperature. According to Kumar and Lal (2012), mulching reduces soil temperature in summer and raises it in winter. Mulching also prevents extremes of temperature. The consistent high temperature under black plastic mulch is due to the green house effect that trap the little radiant energy and penetrates into the soil. Little energy is lost through evaporation, resulting in a net gain of soil heat during the day.

\section{Reduced fertilizer leaching}

As excessive rainfall is shed drained the root zone, thus the fertilizer loss due to leaching is reduced. This is particularly true in sandy soils. This allows the grower to place more pre plant fertilizer in the row prior to planting the crop.and thus fertilizer loss due to leaching is reduced which allows the grower to place more pre plant fertilizer prior to planting the crop. Hundal et al. (2000) revealed that the uptake of nutrients is significantly higher in mulched plots over unmulched plots in tomato. According to Worthington (2001), an increase in available nitrogen contents stimulates protein production, in cabbage following serradella and vetch mulches. Muhammad et al. (2009) observed that mulched treatments show significantly greater total uptake of nitrogen, phosphorus and potassium than unmulched ones. Mulch protects the surface of the soil against unfavorable factors, reduces nutrient leaching and improves growing conditions for vegetables (Baumann et al., 2000; Kolota and Adamczewska Sowiñska, 2004).

\section{Add organic matter}

Organic mulches improve the physical, chemical and biological properties of the soil after decomposition thus return organic matter and plant nutrients to the soil andwhich in turn increases crop yield. Soil under the mulch remains loose, friable and leading to suitable environment for root penetration. The organic mulches not only conserve the soil moisture, but they also increase the soil nutrients through organic matter addition. Saroa and Lal (2003) and Khurshid et al. (2006) concluded that organic matter was significantly higher when more mulch was applied. Higher organic carbon content of soil was recorded with sunhemp mulch $(0.71 \%)$ followed by silkworm bed waste $(0.68 \%)$, paddy straw $(0.66 \%)$ mulched plots and least organic carbon content $(0.48 \%)$ in non-mulched plot (Shashidhar et al., 2009). Similar results were shown by $\mathrm{Ni}$ et al. (2016) and Lalitha et al. (2010).

\section{Stimulate soil micro-flora}

Mulching stimulates the soil micro-flora such as algae, mosses, fungi, bacteria, actinomycetes and also other organisms like earth worms etc., owing to loose the soil, well aerated soil conditions, maintain uniform moisture and temperatures thus helps in resulting the more rapid breakdown of organic matter in the soil and release of plant nutrients for crop growth. According to Brown et al. (2001) mulching practices gave positive effect on the soil biota. Soil biota increase under mulched soil environment thereby improving nutrient cycling and organic matter build up over a period of several years. Sugiyarto (2009) showed that application of maize residue as mulch enhanced diversity index of surface and deep soil macroinvertebrate, i.e: 0.215 and 0.214 (by $44 \%$ and $73 \%$ respectively as compared to no mulching). Shashidhar et al. (2009) reported more number of bacterial, fungal and actinomycetes colonies found in Cassia sericea (32 CFU x 105/g), paddy straw (53 CFU $\times 104 / \mathrm{g}$ ) and sunhemp (53 CFU x 103/g) mulched plots over other treatments respectively. Bhagat et al. (2016), Bandopadhyay et al. (2018) and Bandopadhyay et al. (2020) also reported the similar results of the plastic films on the enhanced soil microorganisms activity.

\section{Plant growth and development}

Reduced evaporation is the major cause for the plant growth and development. Mulching provides the better environment for the plant growth. Therefore, both the above said factors in combination results in vigorous and healthy plant which becomes resistant to the plant growth, also ensures the early plant growth than the unmulched plants. Muching regulates the soil moisture and temperature which helps to stimulate the faster root growth and thus stimulates the better plant growth. Lourduraj et al. (1996) obtained highest plant height $(81.5 \mathrm{~cm})$ and number of laterals (8.6 per plant) in tomato cv. "CO-3" with the application of black LLDPE mulch as compared to organic mulch and no mulch. According to Gao et al. (2001) the nutrient paper mulch (NPM) advanced the plant growth as compared to plastic mulch and no mulch in tomato. Angmo et al., 2018 and Kumari et al., 2018. also reported the similar results.

\section{Improved quality and yield}

Rajablariani et al. (2012) in tomato grown on polyethylene mulch films and bare soil reported that number of branches and leaves were better for the plants grown over plastic compared to bare soil. The highest early yield was obtained in clear plastic likely due to light entrance and raising soil temperature. Mulching increased marketable yield relative to bare soil as the plants grown on silver/black plastic mulch indicated a $65 \%$ increasing in marketable mulch compared to control treatment. Marketable yield increased by $65 \%$ in 
silver/black followed black $(50 \%)$, blue $(40 \%)$, red $(26 \%)$ and clear plastic mulch (24\%). The increase in yield of mulched plot was probably associated with the conservation of moisture, reduced insects pests and improved microclimate both beneath and above the soil surface and also the greater weed control, especially in silver/black and black plastic mulch.

Hassan et al. (1994) reported that organic mulch gave highest fruit yield of bell pepper over control. Gao et al. (2001) reported that the nutrient paper mulching (NPM) promoted flower bud differentiation, enhanced yield and improved fruit quality in tomato as compared to the plastic mulch or no mulching. Similar are the findings of Singh et al. (2009) in tomato and Ashrafuzzaman et al. (2011) in chillies reported that at the maturity, the tallest plant $(78.45 \mathrm{~cm})$ was observed in transparent, followed by black $(77.58 \mathrm{~cm})$ and blue $(77.03 \mathrm{~cm})$ plastic.

\section{Promotes Earlier Harvest}

Black mulch when applied to the planting bed (prior to planting) will warm the soil and promote faster growth in early season, which generally leads to earlier harvest. Whereas, clear mulch also warmth the soil more rapidly than black mulch and usually provides even earlier harvest. Warm season vegetable, such as cucumbers, muskmelons, watermelons, eggplant, peppers, usually respond well to mulching in terms of early maturity and more yields. The main reason for earlier maturity is probably due to maintenance of favourable soil temperatures during the particular growing season. Beneficial effect of polyethylene mulch on the increase of the early yield was also found for watermelon (Romic et al., 2003), tomato (Brown et al., 2001; Hutton et al., 2007) and pepper (Hutton et al., 2007). Similar are the findings of Bhujbal et al. (2015) in tomato, Basamma and Shanmugasundaram (2016) in hybrid tomato, Singh et al. (2017) in tomato and Kumari et al. (2018) in tomato also.

\section{CONCLUSION}

In the present scenario of globalization and health consciousness demand for horticultural crops has increased world over. Excessive competition has not only compelled us to produce more but also to produce quality fruits for sustaining in the international market. Mulching increased growth and fruit yield of vegetable crops through modification of the crop growing environment by reducing weed infestation, soil moisture depletion and ameliorating soil temperatures. This helps to reduce the herbicide use, thus prevents environment pollution. Plastic mulches directly impact the microclimate around the plant by modifying the radiation budget (absorbitivity vs. reflectivity) of the surface and decreasing the soil water loss. Black, white and clear plastic mulches are most commonly used in commercial production with black being the dominant colour used for vegetables. Colour affects the surface temperature of the mulch and the underlying soil temperature. Though very effective and affordable, plastic mulch has become an environmental management concern due to disposal issues.
Research has shown that mulch provides many benefits to crop production such as protecting the roots of the plants from heat and cold, creating congenial condition for the plant growth by temperature moderation, reducing salinity and weed control and thereby improving the yield and quality of the crop. Therefore in the days to come, farmers will make use of this innovative technique that helps them conserve moisture, avoid weeds and improve soil health tremendously while producing more. Mulching is one such process that can help us in producing quality food in quantities apart from good agricultural practices. There is a great need to utilize the biological and environmental energy for the higher production. This will also go a long way in the world achieving food security sustainably.

\section{REFRENCES}

Abu-Awwad, A.M. (1999). Irrigation water management for efficiency water use in mulched onion. Journal of Agronomy and Crop Science. 183: 1-7.

Angmo, S., Bhatt, R.P., Paljor, E., Dolkar, P., Kumar, B., Chaurasia, O.P. and Stobdan, T. (2018). Black polyethylene mulch doubled tomato yield in a low-input system in arid trans himalayan ladakh region. Defence Life Science Journal. 3(1): 80-84.

Arora, J.S., Amanpreet, K., Sidhu, G.S. and Kaur, A. (2002). Performance of carnation in polyhouse. Journal of Ornamental Horticulture, New Series 5: 58-63.

AshrafuzzaMan, M., Halim, A., Ismail, M., Shahidullah, S. and Hossain, A. (2011). Effect of plastic mulch on growth and yield at chilli. Brazilian Archives of Biology and Technology. 54(2): 321-30.

Basamma, K.A. and Shanmugasundaram, K. (2016). Influence of open field mulching on growth and yield of hybrid tomato under drip fertigation. Enviroment and Ecology. 34(2): 416-20.

Baumann, D.T., Kropff, M.J. and Bastiaans, L. (2000). Intercropping leeks to suppress weeds. Weed Research. 40: 359-74.

Bandopadhyay, S., Martin-Closas, L., Pelacho, A.M. and DeBruyn, J.M. (2018). Biodegradable Plastic Mulch Films: Impacts on Soil Microbial Communities and Ecosystem Functions. Frontiers of Microbiology. doi: 10.3389/fmicb.2020. 587074.

Bandopadhyay, S., Sintim, H.Y. and DeBruyn, J.M. (2020). Effects of biodegradable plastic film mulching on soil microbial communities in two agroecosystems. Peer Reviwed Journal. doi: 10.7717/peerj.9015.

Bhagat, P., Gosal, S.K. and Singh, C.B. (2016). Effect of mulching on soil environment, microbial flora and growth of potato under field conditions. Indian Journal of Agricultural Research. 50(6): 542-48.

Bhavani, J.K. (1960). Role of mulch and cultural practices and its influence on growth and yield of Bhokri grapes (Vitis vinifera Linn.). M.Sc. (Ag.) Thesis Submitted to Poona University, Poona.

Bhujbal, P.D., Tambe, T.B. and Ulemale, P.H. (2015). Effects of mulches on flowering, fruiting, yield and pest-disease incidence of tomato (Lycopersicon esculentum mill.). The Bioscan. 10(1): 465-68. 
Brown, G.G., Pasini, A., Benito, N.P., De Aquino, A.M. and Correia, M.E.F. (2001). Diversity and functional role of soil macrofauna communities in Brazilian no-tillage agro-ecosystems: A preliminary analysis. International Symposiumon Managing Biodiversity in Agricultural Ecosystems, Montreal. 8-10 November 2001.

Chen, Y. and Katan, J. (1980). Effect of solar heating of soils by transparent polyethylene mulching on their chemical properties. Soil Science. 130: 271-77.

Dilip, K.G., Sachin, S.S. and Rajesh Kumar. (1990). Importance of mulch in crop production. Indian Journal of Soil Conservation. 18: 20-22.

Erenstein, O. (2002). Crop residue mulching in tropical and semitropical countries: An evaluation of residue availability and other technological implications. Soil and Tillage Research. 67: 115-33.

Farias-Larios, J. and Orozco-Santos, M. (1997b). Color polyethylene mulches increase fruit quality and yield in watermelon and reduce insect pest populations in dry tropics. Gartenbauwissenschaft. 62: 255- 60.

Gao, G.X., Jin, L.Z., Guo, F.C., Gu, Z.H., Yu, Y. and Chen, B. (2001). Effect of nutrient paper mulching on tomato (Lycopersicon esculentum) cultivation. China Vegetables. 6: 6-7.

Hassan, S., Abidin, R. and Ramlan, M. (1995). Growth and yield at chili in response to mulching and potassium fertilization. Pertanika J. Trop. Agri. Sci. 18(2): 113-117.

Hatfield, J.L., Sauer, T.J. and Prueger, J.H. (2001). Managing soils to achieve greater water use efficiency: A review. Agronomy Journal. 93: 271-80.

Hundal, I.S., Sandhu, K.S., Singh, D and Sandhu, M.S. (2000). Effect of different types of mulching and herbicidal treatments on nutrient uptake in tomato (Lycopersicon esculentum). Haryana Journal of Horticulture Science. 29: $242-44$.

Hutton, M.G. and Handley, D.T. (2007). Effects of silver reflective mulch, white inter-row mulch and plant density on yields of pepper in Maine. Hort. Technology. 17: 214-19.

Kader, M.A., Senge, M., Mojid, M.A. and Ito, K. (2017). Recent advances in mulching materials and methods for modifying soil environment. Soil and Tillage Research. 168: $155-66$.

Kumar, D.S. and Lal, R.B. (2012). Effect of mulching on crop production under rainfed condition: A review. International Journal of Research in Chemistry and Environment. 2(2): 8-20.

Khurshid, K., Iqbal, M., Arif, M.S. and Nawaz, A. (2006). Effect of tillage and mulch on soil physical properties and growth of maize. International Journal of Agriculture and Biology. 8: 593-96.

Kolota, E. and Adamczewska-Sowiñska, K. (2004). The effects of living mulches on yield, over wintering and biological value of leek. Acta Horticulture. 638: 209-14.

Kumari, C., Kumar, B. and Kumar, M. (2018). Utilization of polythene mulching under protected cultivation of tomato: A method to minimize amount of irrigation under semi arid ecosystem of Jharkhand, India. International Journal of Current Microbiology and Applied Sciences. 7(08): 4315-320.
Lamont, Jr.W.J. (2005). Plastics: Modifying the microclimate for the production of vegetable crops. Hort. Technology. 15: 477-81.

Lalitha, M., Kasthuri Thilagam, V., Balakrishnan, N. and Mansour, M. (2010). Effect of plastic mulch on soil properties and crop growth - A review. Agricultural Review. 31(2): 145-49.

Lourduraj, A.C., Sreenarayanan, V.V., Rajendran, R., Ravi, V., Padmini, K. and Pandiarajan, T. (1996). Effect of plastic mulching on tomato yield and economics. South Indian Horticulture. 44: 139-42.

Mohapatra, B.K., Naik, P., Lenka, D. (1999). Efficiency of plastic mulching in tomato. Environment and Ecology. 17: 775776.

Muhammad, A.P., Muhammad, I., Khuram. S. and Anwar-UL-Hassan. (2009). Effect of mulch on soil physical properties and NPK concentration in Maize (Zea mays) shoots under two tillage system. International Journal of Agricultureand Biology. 11: 120-24.

Murugan, M. and Gopinath, G. (2001). Effect of organic and inorganic mulches on growth and flowering of crossandra (Crossandra undulaefolia Salisb) cv. Saundarya. Research on Crops. 2: 346-50.

NNi, X., Song, W., Zhang, H., Yang, X. and Wang, L. (2016). Effects of mulching on soil properties and growth of Tea Olive (Osmanthus fragrans). PloS ONE. 11(8): e0158228. https://doi.org/10.1371/journal.pone.0158228.

Ossom, E.M., Pace, P.F., Rhykerd, R.L. and Rhykerd, C.L. (2003). Influence of mulch on soil temperature, nutrient concentration, yield components and tuber yield of sweet potato (Ipomea batatus). Indian Journal of Agricultural Sciences. 73: 57-9.

Pimpini, F. (1974). Chemical weed control in a semi-forced crop of gladiolus. Rivista di Agronomia. 8: 335-43.

Rajablariani, H., Hassan Khan, F. and Rafezi, R. (2012). Effect at colored plastic mulches on yield at tomato and weed biomass. International Journal of Environmental Science and Development. 3(6): 590-593.

Ravi, V. and Lourduraj, A.C. (1996). Comparative performance of plastic mulching on soil moisture content, soil temperature and yield of rainfed cotton. Madras Agricultural Journal. 83: 709-711.

Romic, D., Borosic, J., Poljak, M. and Romic, M. (2003). Polyethylene mulches and drip irrigation increase growth and yield in watermelon (Citrullus lanatus L.). European Journal of Horticultural Science. 68: 192-98.

Saroa, G.S. and Lal, R. (2003). Soil restorative effects of mulching on aggregation and carbon sequestration in a Miamian soil in Central Ohio. Land Degradation Development. 14: 481-493.

Sarolia, D.K. and Bhardwaj, R.L. (2012). Effect of mulching on crop production under rainfed condition: A Review. International Journal of Research in Chemistry and Environment. 2: 8-20.

Shashidhar, K.R., Bhaskar, R.N, Priyadharshini P. and Chandrakumar, H.L. (2009). Effect of different organic mulches on $\mathrm{pH}$, organic carbon content and microbial status of soil and its influence on leaf yield of M-5 mulberry (Morus indica L.) under rainfed condition. Current Biotica. 2: 405-412. 
Singh, H., Sharma, P., Kumar, P., Dhillon, N.S. and Sekhon, B.S. (2017b). Influence of mulching on growth and yield of tomato (Solanum lycopersicum L.) under protected environment. International Journal of Biotechnology. 19(2): 1-6.

Singh, R., Kumar, S., Nangare, D.D. and Meena, M.S. (2009). Drip irrigation and black polythene mulch influence on growth yield and water use efficiency of tomato. African Journal of Agricultural Research. 4: 1427-1430.

Sugiyarto, M. (2009). The effect of mulching technology to enhance the diversity of soil macro invertebrates in sengonbased agro-forestry systems. Biodiversitas. 10: 129-33.
Thakur, P.S., Thakur, A., Kanaujia, S.P., Thakur, A. (2000). Reversal of water stress effects. I. Mulching impact on the performance of Capsicum annuum under water deficit. Indian Journal of Horticulture. 57: 250-54.

Waterer, D.R. (2000). Effect of soil mulches and herbicides on production economics of warm-season vegetable crops in a cool climate. HortTechnology. 10: 154-59.

Worthington, V. (2001). Nutritional quality of organic versus conventional fruits, vegetables and grains. The Journal of Alternative and Complementary Medicine. 7/2: 161-173. 